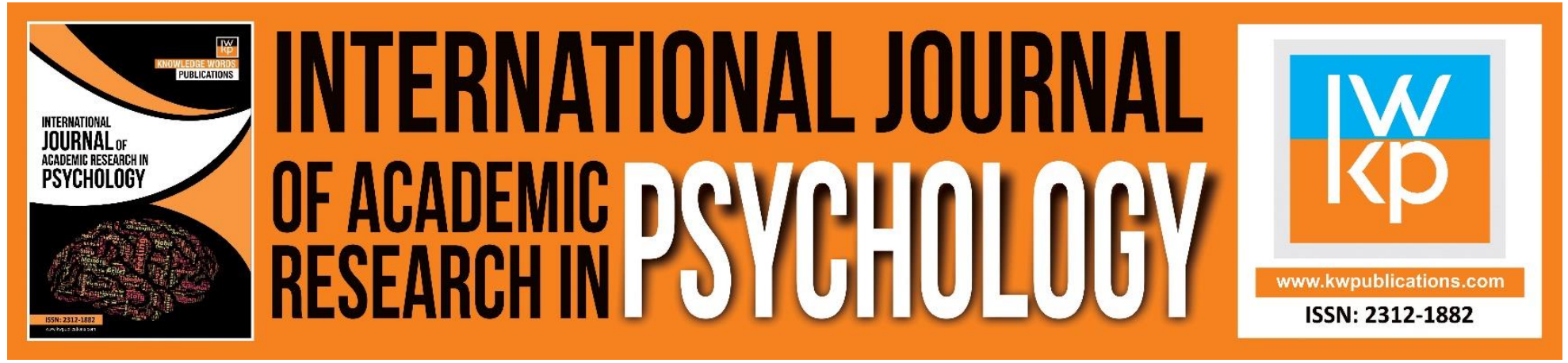

\title{
Preferred Learning Method and Performance among Accounting Students: Does Personality Type Matter?
}

\section{Erlane K Ghani, Suria Majdi and Norbijan Abu Bakar}

To Link this Article: http://dx.doi.org/10.46886/IJARP/v3-i1/2227

DOI:10.46886/IJARP/v3-i1/2227

Received: 02 February 2016, Revised: 18 April 2016, Accepted: 19 May 2016

Published Online: 28 May 2016

In-Text Citation: (Ghani et al., 2016)

To Cite this Article: Ghani, E. K., Majdi, S., \& Abu Bakar, N. (2016). Preferred Learning Method and Performance among Accounting Students: Does Personality Type Matter? International Journal of Academic Research in Psychology. 3(1), 11-25.

Copyright: (c) 2016 The Author(s)

Published by Knowledge Words Publications (www.kwpublications.com)

This article is published under the Creative Commons Attribution (CC BY 4.0) license. Anyone may reproduce, distribute, translate and create derivative works of this article (for both commercial and non-commercial purposes), subject to full attribution to the original publication and authors. The full terms of this license may be seen at: http://creativecommons.org/licences/by/4.0/legalcode

Vol. 3, No. 1, 2016, Pg. 11 - 25

https://kwpublications.com/journals/journaldetail/IJARP

JOURNAL HOMEPAGE

Full Terms \& Conditions of access and use can be found at https://kwpublications.com/pages/detail/publication-ethics 


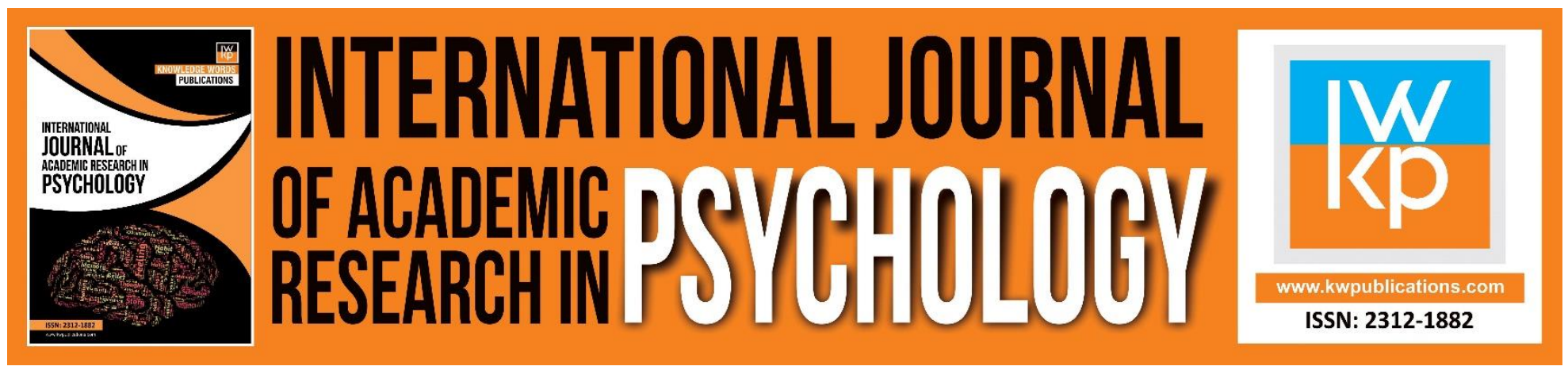

\title{
Preferred Learning Method and Performance among Accounting Students: Does Personality Type Matter?
}

\author{
Erlane K Ghani, Suria Majdi and Norbijan Abu Bakar \\ Faculty of Accountancy, Universiti Teknologi MARA, Malaysia \\ Email: erlanekg@salam.uitm.edu.my
}

\begin{abstract}
This study examines the personality profile of accounting students in a public university in Malaysia. Specifically, this study determines whether students' personality influence their preferred learning method. This study follows Jung and Myer Briggs' study that provides 16 personality types which subsequently theme up into four types of personality. The four types of personality are Extroverts versus Introverts, sensing versus Intuitive, thinking versus Feeling and Judging versus Perceiving. The focus of this study is on two types of personality namely, Extrovert versus Introvert and Sensing versus Intuitive. Using questionnaire survey on 266 students, this study found students' personality type influence their preferred learning method. Further analysis shows that students possessing Extrovert Intuition has the most different preference learning method as compared to students with other personality type. The results also show that students' personality type also influence their performance. Further analysis shows that students possessing Extrovert Intuition performed much better compared to the students with other personality type. The findings in this study provide further understanding to the academics, faculties and university on the type of personality of the accounting students and their preferred learning method. Such understanding provides these parties guidelines on the factors to be concentrated in improving teaching and learning in accounting education.
\end{abstract}

Keywords: Personality, Personality Type, Students, Accounting, University, Malaysia.

\section{Introduction}

Students are different with respect to their profile and the way they assess meaning and acquiring information (Mattar and El Khoury, 2012). The importance of understanding students' profile is not only evident to students but also to the faculties and universities as it can become a contributing factor to their educational success. Personality type refers to the psychological classification of different types of individuals. Many universities generate students' profile for recordkeeping purposes as these profiles are focused on the interests of the students and their courses of study. The recordkeeping of the students profile assist the universities to gather information in order to 
make better educational decisions that will enhance the students' development. However, most of the students' profile is related to extrinsic information such as their origin and previous course taken, leaving the inclusion of intrinsic information such as personality type.

The psychology literature defines personality type as psychological of different types of individuals. A large body of the psychology literature examined personality because studies have shown that students have different ways of responding and preference to learning method. The mismatch between personality type and learning method would result to negative impact on their performance. However, examining such issue in the context of accounting is still under-examined. It is undeniable that the psychology research needs to be relied upon in studying human information processing (Nourayi and Cherry, 1993). Nourayi and Cheery argued that accounting researchers need to look into the psychology perspective and learned from that discipline.

This study examines the personality profile of the accounting students in a public university in Malaysia. Specifically, this study identifies the type of personality possess by the final year undergraduate accounting. This study subsequently examined the effect of the students' personality on their preferred learning method. The findings in this study provide further understanding to the academics, faculties and university on the type of personality of the accounting students and their preferred learning method. The remainder of this paper is structured as follows. The next section provides a review of relevant literature. Section 3 discusses the hypotheses underpinning this study and section 4 outlines the research design. The results are presented in section 5. A summary and conclusion are provided in the last section.

\section{Literature Review}

One of the most eminent areas being examined in the education literature is examining the factors that could influence students' performance. Most studies supported the notion that students' performance could be affected by different socio-economic, psychological and environmental factors (Hijazi and Naqvi, 2006). These factors include gender (Anderson et al. 1994; Horne, 2000), similar learning styles between the students and instructors (Borg and Shapiro, 1996), sitting location in the class (Topping, 1994), attendance (Park and Kerr, 1990; Durden and Ellis, 1995) and their previous results (Nordstrom, 1990). Although there are studies that have examined psychological factors, the issue of personality type however, is still under-researched.

Personality refers to "similar responses" to internal or external stimuli, where certain persons with similar traits would respond to the stimuli in a similar manner (Meisgeier et al., 1989; Rogers, 1993). Proponents of the personality theory strongly hold the belief that an environment in which learning occurs positively influences the students' performance if the environment favors their personality type (Rogers, 1993). Several studies have supported the arguments of the proponents in the context of organizational environments such as the workplace (Rorer, 1992; Kummerow et al., 1997). The findings of these studies have led few researchers to suggest that structuring the classroom based on the students' personality would assist the students to achieve targeted results (Meisgeier et al., 1989; Rogers, 1993). However, most studies that have examined the impact of personality type within the classroom were not in quantifiable manner. 
Studies have also shown that students that have different personality style influence them to have different learning styles, that consequently reflected in different academic strengths, skills, and interests (Borg and Stranahan, 2002; Felder et al., 2002; Russo and Kaynama, 2012). Arguably, the students particularly the accounting students are not an exception to this. Since there is a variety of job description within the accounting field, the students may have equal chance and potential to become successful accountants. However, their chance and potential to become successful accountants may be deterred by their different ways of responding and preference to the different type of learning methods due to their personality type. Therefore, identifying the personality type of students seems necessary in order to provide and design a more balanced teaching and learning methodologies that is effective for all students.

In the accounting discipline, there are studies that have examined personality type of the accounting students (Nourayi and Cherry, 1993; Bealing et al., 2006; Bealing et al., 2007; Bealing et al., 2008; Swain and Olsen, 2012; Fallan and Opstad, 2013). However, only few of these studies have examined the effect of personality type on students' performance. For example: Nourayi and Cherry (1993) examined the effect of link between accounting students' performance and personality types on 103 students. They used questionnaire survey to identify the personality type of the students and their sample was dichotomised based on gender. They found that there is no significant difference between the two groups of students. They also found no significant difference between Sensing versus Intuitive students in terms of performance. Their results indicate that the future accountants do not possess a dominant personality type. However, their sample focused on first intermediate accounting course. On the other hand, Bealing et al (2007) examined six specific questions that are related to Sensing and Intuitive dimensions of Jungian personality type. They examined whether there is a correlation between the strength of a student's specific personality preferences and their result in their introductory accounting course. They found students with Sensing dimension performed better than students with Intuitive dimension. Although both Nourayi and Cherry's study and Bealing et al.'s study have relied on students in the introductory accounting course, their findings may not be generalised to final year accounting students. Both studies however, have relied on Jung and Myers-Briggs Personality Type Indicator.

\section{Jung and Myers-Briggs Personality Type Indicators}

Jung (1923) suggested that individuals possess specific personality types. He described a set of dichotomous differences in individuals in which he defined as Extrovert and Introvert. Extrovert and Introvert refer to the way individuals prefer to "focus their attention" and "gain their energy" (Myers, 1998). Extroverts focus their attention and gain energy through interaction with the external world of people, activities and things. Introverts on the other hand, focus their attention and gain energy through the inner world of ideas, impressions, and emotions. Extroverts prefer communicating using discussion and interacting whilst Introverts prefer written communication. Felder et al (2002) noted that students with different personality type tend to respond differently to different teaching and

learning instruction. Extraverts prefer to work in settings that provide for activity and group work whilst Introverts prefer to work in settings that provide opportunities for internal processing. 
Jung later expanded his concepts to include another dichotomous set of personality types namely, Sensing and Intuition (Storr, 1983). Sensing and Intuition involve how individuals gather and process information (Schloemer and Schloemer, 1997). Sensing individuals tend to organise input sequentially and prefer detailed instructions with concrete information. Intuitive individuals on the other hand start with broad concepts seeing patterns, connections and trends organizing them as a more workable general framework. Intuitive type may not prefer detailed oriented activities, preferring to process information in a top down format as opposed to the Sensing type that prefer detailed, fact based bottom up approach. Jung has also introduced Thinking versus Feeling which deal with the way individuals make decisions (Schloemer and Schloemer, 1997).

Myers and Briggs extended Jung's concept to include another set of psychological type known as Judging versus Perceiving (Myers, 1976). Myers (1998) described the Judging type as those who prefer to be planned, organised, and prefer closure and the settling of things. On the other hand, the Perceiving type is those who is less planned and may prefer to keep his options open. The Judging type may be more organized whilst the Perceiving type may be more spontaneous based on their reliance on their ability to adapt to a changing situation. They then developed a personality type indicator to determine the personality type of an individual. The personality type indicator would determine whether an individual is an Extrovert or Introvert, Sensing or Intuitive, Feeling or Thinking and Judging or Perceiving.

This study focuses on two types of personality namely, Extroverts versus Introverts and Sensing versus Intuitive due to their dominancy in the psychological literature when examining students' personality but under-researched in the accounting discipline. Felder et al. (2002) noted that students with different personality type tend to respond differently to different teaching and learning instruction.

\section{Research Question and Hypotheses Development Objectives of Study}

This study attempts to determine the personality type of the accounting students in a public university in Malaysia. Specifically, this study examines:

i. The personality profile of the final year accounting students.

ii. The effect of the final year students' personality type on their preferred learning method.

iii. The effect of the final year students' personality type on their performance.

The objectives of this study are achieved by way of a questionnaire survey.

\section{Development of Research Question}

Studies have suggested that accounting students are likely to be successful accountants if they not only possess extrinsic factors such as previous educational background but also intrinsic factors such as personality. These studies suggested the need to look into psychology discipline and learned from this discipline in order to obtain further understanding on the factors that influence students' performance. In particular, studies need to look at Jung's theory that has proposed three types of 
personality namely, Extroverts versus Introverts, Sensing versus Intuitive and Thinking versus Feeling. Myers-Briggs then extended Jung's concepts by introducing Judging versus Perceiving and developed the Myers-Briggs Personality Type Indicator in measuring or determining the personality of individuals.

Within the accounting education, a group of studies have examined students' personality in accounting discipline such as Bealing et al (2006); Swain and Olsen (2012); Fallan and Opstad (2013). These studies found that accounting students possess different personality. For example: Swain and Olsen (2012) examined the pattern of personality types of students that come into introductory accounting classes. Their study examines both the accounting education decision, and the decision to pursue and remain with an accounting career. They demonstrated most of the students are Sensing individuals in which they prefer to gather information based on observations of concrete data rather than gathering insight based on an intuitive exploration of meanings and relationships (Intuitive). However, their study focused on junior accounting students and on one of the personality type namely, Sensing versus Intuitive. Following Swain and Olsen, this study aims to examine the personality type of the final year accounting students in terms of Extroverts versus Introverts and Sensing versus Intuitive. Therefore, the following research question is developed:

RQ1: What is the personality profile of the final year accounting student?

\section{Development of Research Hypotheses}

Studies have shown that students that have different personality style influence their learning styles that consequently reflected in different academic strengths, skills, and interests (Borg and Stranahan, 2002; Felder et al., 2002; Bisping and Eells, 2006; Swope and Schmitt, 2006; Russo and Kaynama, 2012). These studies however were conducted in a non-accounting discipline. It is likely that accounting students would also portray similar behavior in which different personality would prefer different preference in learning method. Therefore, this study develops the following hypothesis:

H1: There is a significant difference on the preferred learning method among the students with different personality.

One of the factors that have also been suggested in the literature that could influence students' performance is their personality style (Nourayi and Cherry, 1993; Felder et al., 2002; Bealing et al., 2007). These studies suggested that students that have different personality style that leads them to have different learning styles that consequently reflected in their performance (Felder et al., 2002). However, the findings shown in the accounting discipline are mixed. Nourayi and Cherry (1993) found no significant difference between Sensing versus Intuitive students in terms of performance. Their results indicate that the future accountants do not possess a dominant personality type. On the other hand, Bealing et al., (2007) found students with Sensing dimension performed better than students with Intuitive dimension. Although both Nourayi and Cherry's study and Bealing et al.'s study have relied on students in the introductory accounting course, their findings may not be able to be generalised to final year accounting students. Their contrasting findings led this study to further examine this issue. Therefore, the following alternate hypothesis is developed: 
INTERNATIONAL JOURNAL OF ACADEMIC RESEARCH IN PSYCHOLOGY

Vol. 3, No. 1, 2016, E-ISSN: 2312-1882 @ 2016 KWP

H2: There is a significant difference on the performance among the students with different personality.

\section{Research Design}

\section{The Respondents}

The final year accounting students who were enrolled in two different semesters over a period of one year in a public university are chosen as the respondents in this study. These students are chosen to become the respondents in this study because they are towards graduation and therefore, have gone through rigorous courses that have to be completed to be entitled for a Bachelor of Accountancy.

\section{Research Instrument}

This study uses questionnaire survey as the research instrument. The questionnaire was developed based on Bealing et al. (2006); Swain and Olsen (2012). The questionnaire is divided into two sections. Section A requests the respondents to provide their opinion related to their personality type. There are 20 questions related to personality type. The questions include whether they prefer pre-arranged schedules or they describes themselves as analytical or free-spirited and their interest in doing things the most logical way or in the traditional way. The respondents are also requested to identify whether they are methodical or spontaneous, their preference in class projects, how their friends describe them and whether they are conventional or creative. Other questions include their preference when waiting in a long line on whether they prefer to chat with the person next to them or keeping their eyes on the phone, and also whether they find it common that often they are ruled by their heart or vice versa. The results in this section would determine the personality type of the respondents. The respondents are required to complete this section based on categorical scale. Subsequently, personality type of the final year accounting students becomes the independent variable of this study.

Section $B$ requests the respondents to complete their demographic profile. There are 5 questions divided into 2 parts in this section. Part $A$ requests the respondents to identify their gender and origin. Part $B$ requests the respondents to identify their preferred learning method and CGPA to date. The respondents are required to choose their preferred learning method of either academics providing the lecture only, students presenting using the PowerPoint or Students performing role play or discussion. The respondents are required to complete all the questions in this section based on categorical scale except for CGPA to date. For this question, the respondents are requested to state their exact CGPA score. Preferred learning method and performance are the dependent variables in this study.

\section{Data Collection and Analyses}

The data collection was performed over a six months period from 1 January 2016 to 30 June 2016. The questionnaires were distributed during class hours with the assistance of the teaching academics. The respondents were requested to complete and return the questionnaire to their teaching academics. The data was collected in this manner to reduce the possibility of low response. In total, 350 questionnaires were distributed to the students. Out of the 350 questionnaires distributed, 326 
INTERNATIONAL JOURNAL OF ACADEMIC RESEARCH IN PSYCHOLOGY

Vol. 3, No. 1, 2016, E-ISSN: 2312-1882 @ 2016 KWP

respondents returned the questionnaire. However, only 266 returned questionnaires were completed, resulting in a response rate of $76.0 \%$ percent. The data was then analysed using SPSS.

\section{Results}

\section{Demographic Attribute}

This section presents the results of answering the research question in this study. The research question in this study poses the question "What is the personality profile of the final year accounting student? The results of the descriptive analysis of the demographic attribute of the respondents are provided in Table 1. Panel A of Table 1 sets out the results of the descriptive statistics of demographic attribute in terms of gender and origin. Table 1 shows that 201 (75.6 percent) of the total respondents are female and only 65 (24.4 percent) are male students. This is not unusual as most accounting students in the public universities in Malaysia are being dominated by female.

Panel B, Table 1 presents the results of the frequency descriptive statistics of the personality type. The results in panel A, Table 2 show that 31.2 percent are Extrovert Sensing students (83 respondents) compared to 34.2 percent are Extrovert Intuitive students (91 respondents). Only 41 students (15.4 percent) are Introvert Sensing and 51 students (19.2 percent) are Introvert Intuitive. The results indicate that there are more Extroverts compared to Introverts among the final year students, results which are unexpected since previous studies have shown that accounting students are often more quiet and reserve than the students in other disciplines. However, it is surprising to have results that show more Intuitive students than Sensing students since accounting students are often expected to have logical senses rather than following their intuition.

Panel C, Table 2 provides a more detailed insight on the final year accounting students' personality profile. The results show that there are female Extrovert Intuitive (69 respondents) as compared to female Extrovert Sensing (62 respondents). Similarly, there are more female Introvert Intuitive (37 respondents) as compared to 33 Introvert Sensing. The results show that there are slightly more of male Extrovert Intuitive (22 respondents) compared to 21 male Extrovert Sensing. Similarly, there are more male Introvert Intuitive (14 respondents) as compared to only 8 Introvert Sensing. The results indicate that more of the accounting students possess the personality of Extroverts and more than half of them possess the personality of intuition. Again, this is quite surprising because accounting is a course that requires logical senses and yet more students that possess of the nature of perceiving enrolled for accounting courses. 
INTERNATIONAL JOURNAL OF ACADEMIC RESEARCH IN PSYCHOLOGY

Vol. 3, No. 1, 2016, E-ISSN: 2312-1882 @ 2016 KWP

Table 1: Demographic Attribute

Panel A: Gender

\begin{tabular}{lccc}
\hline & Frequency & Percent & Cumulative Percent \\
\hline Male & 65 & 24.4 & 24.4 \\
Female & 201 & 75.6 & 75.6 \\
Total & 266 & 100 & 100 \\
\hline
\end{tabular}

Panel B: Personality Type

\begin{tabular}{lccc} 
& Frequency & Percent & Cumulative Percent \\
\hline Extrovert Sensing & 83 & 31.2 & 31.2 \\
Extrovert Intuitive & 91 & 34.2 & 65.4 \\
Introvert Sensing & 41 & 15.4 & 80.8 \\
Introvert Intuitive & 51 & 19.2 & 100.0 \\
Total & 266 & 100 & \\
\hline
\end{tabular}

Panel C: Personality Type and Gender

\begin{tabular}{lccccc} 
& \multicolumn{4}{c}{ Personality } & Total \\
\cline { 2 - 5 } & $\begin{array}{c}\text { Extrovert } \\
\text { Sensing }\end{array}$ & $\begin{array}{c}\text { Extrovert } \\
\text { Intuitive }\end{array}$ & $\begin{array}{c}\text { Introvert } \\
\text { Sensing }\end{array}$ & $\begin{array}{c}\text { Introvert } \\
\text { Intuitive }\end{array}$ & \\
\hline Male & 21 & 22 & 8 & 14 & 65 \\
Female & 62 & 69 & 33 & 37 & 201 \\
Total & 83 & 91 & 41 & 51 & 266 \\
\hline
\end{tabular}

\section{Effect of Students' Personality Type on Preferred Learning Method}

This section presents the results of testing hypothesis 1 . Hypothesis 1 states that "There is $a$ significant difference on the preferred learning method among the students with different personality". Panel A of Table 2 provides some hindsight on the preferred learning methods among the students with different personality. The results show that the students possessing intuitive in nature tends to prefer their academics providing the lecture to them. On the other hand, students with senses prefer to have their learning method to be either presentation or role play or discussion. Surprisingly Extrovert students tend to prefer their academics to lecture rather than them presenting in front of the class, or role play or discussion.

Table 2: Personality Type and Preferred Learning Method

Panel A: Descriptive Statistics

\begin{tabular}{ccccc}
\hline Personality Type & $\mathrm{N}$ & Mean & Std. deviation & Std. error mean \\
\hline Extravert Sensing & 83 & 2.35 & & \\
Extrovert Intuition & 91 & 1.84 & 1.017 & 0.112 \\
Introvert Sensing & 41 & 2.71 & 1.014 & 0.106 \\
Introvert Intuition & 51 & 2.35 & 1.270 & 0.198 \\
Total & 266 & 2.23 & 1.128 & 0.158 \\
\hline
\end{tabular}


INTERNATIONAL JOURNAL OF ACADEMIC RESEARCH IN PSYCHOLOGY

Vol. 3, No. 1, 2016, E-ISSN: 2312-1882 @ 2016 KWP

Panel B: ANOVA

\begin{tabular}{cccccc} 
& Sum of Squares & df & $\begin{array}{c}\text { Mean } \\
\text { square }\end{array}$ & $F$ & Sig. \\
\hline Between groups & 25.481 & 3 & 8.494 & 7.284 & 0.000 \\
Within groups & 305.530 & 262 & 1.166 & & \\
$\quad$ Total & 331.011 & 265 & & & \\
\hline
\end{tabular}

Panel B of Table 2 presents the results of testing hypothesis 1 . Hypothesis 1 states that "There is $a$ significant difference on the preferred learning method among the students with different personality. The ANOVA was used to determine whether personality type influence learning method of students. The results show that there is a difference in the preferred learning method of students with different personality types. The results show a significant difference at $p=0.000$, thus supporting Hypothesis 1 .

Table 3: Post Hoc Test

\begin{tabular}{|c|c|c|c|c|c|c|}
\hline \multirow[t]{2}{*}{ Personality } & \multirow[t]{2}{*}{ Other Personality } & \multirow{2}{*}{$\begin{array}{c}\text { Mean } \\
\text { Difference }\end{array}$} & \multirow{2}{*}{$\begin{array}{c}\text { Standard } \\
\text { Error }\end{array}$} & \multirow[t]{2}{*}{ Sig. } & \multicolumn{2}{|c|}{ 95\% Confidence level } \\
\hline & & & & & $\begin{array}{l}\text { Lower } \\
\text { Bound }\end{array}$ & $\begin{array}{l}\text { Upper } \\
\text { Bound }\end{array}$ \\
\hline \multirow{3}{*}{$\begin{array}{l}\text { Extrovert } \\
\text { Sensing }\end{array}$} & Extrovert Intuition & $.514^{*}$ & .164 & 0.002 & 0.19 & 0.84 \\
\hline & Introvert Sensing & -.358 & .206 & 0.084 & -.76 & 0.05 \\
\hline & Introvert Intuition & -.004 & .192 & 0.985 & 0.38 & 0.37 \\
\hline \multirow{3}{*}{$\begin{array}{l}\text { Extrovert } \\
\text { Intuition }\end{array}$} & Extrovert Sensing & -.514 & .164 & 0.002 & -.84 & -.19 \\
\hline & Introvert Sensing & -.872 & .203 & 0.000 & -1.27 & -.47 \\
\hline & Introvert Intuition & -.518 & .189 & 0.007 & -.89 & -.15 \\
\hline \multirow{3}{*}{$\begin{array}{l}\text { Introvert } \\
\text { Sensing }\end{array}$} & Extrovert Sensing & .358 & .206 & 0.084 & -.05 & .76 \\
\hline & Extrovert Intuition & $.872^{*}$ & .203 & 0.000 & .47 & 1.27 \\
\hline & Introvert Intuition & .354 & .189 & 0.119 & -.09 & .80 \\
\hline \multirow{3}{*}{$\begin{array}{l}\text { Introvert } \\
\text { Intuition }\end{array}$} & Extrovert Sensing & .004 & .192 & 0.985 & -.37 & .38 \\
\hline & Extrovert Intuition & .518 & .189 & 0.007 & .15 & .89 \\
\hline & Introvert Sensing & -.354 & .227 & 0.119 & -.80 & .09 \\
\hline
\end{tabular}

This study then proceeds to examine further on the effect of the students' different personality type on their learning method. The Post Hoc test was used to examine the personality type on learning method. Table 3 presents the results. The results show that there is a significant difference between the Extrovert Sensing and Extrovert Intuition. The results a mean difference of 0.514 indicating that 
students with Extrovert Sensing prefer learning method involving PowerPoint presentation and role play or discussion whereas students with Extrovert Intuition prefer their academics providing lecture to them. The results show a significant difference of $p=0.002$. Similarly, there is a marginal significant difference between students with Extrovert Sensing and the students possessing Introvert Sensing $(p=0.084)$ but no significant difference with Introvert Intuition $(p=0.985)$. When comparing students possessing Extrovert Intuition with students possessing other personality types, the results also show significant difference with students with Introvert Sensing $(p=0.000)$ and marginal significant difference with students possessing Introvert Intuition $(p=0.007)$. For students possessing Introvert Sensing, the results show no significant different also with Introvert Intuition $(p=0.119)$.

\section{Effect of Students' Personality Type on Performance}

This section presents the results of testing hypothesis 2. Hypothesis 2 states that "There is $a$ significant difference on the performance among the students with different personality". Panel A of Table 4 provides some hindsight on the performance among the students with different personality. The results show that the students possessing Extrovert Intuition score higher CGPA with a mean score of 3.1930 compared to the other students possessing different personality. This is followed by the students with Introvert Sensing (mean score=3.0420), Introvert Intuition (mean score=3.0304 and Extrovert Sensing with a mean score of 3.0304. The results indicate that students that have the Extrovert Intuition would have better chance to perform better when enrol in accounting courses.

Table 4: Personality Type and Performance

Panel A: Descriptive Statistics

\begin{tabular}{ccccc}
\hline Personality Type & $\mathrm{N}$ & Mean & Std. deviation & Std. error mean \\
\hline Extravert Sensing & 83 & 3.0249 & 0.26454 & 0.0290 \\
Extrovert Intuition & 91 & 3.1930 & 0.33797 & 0.0354 \\
Introvert Sensing & 41 & 3.0420 & 0.34383 & 0.0537 \\
Introvert Intuition & 51 & 3.0304 & 0.22495 & 0.0315 \\
Total & 266 & 3.0861 & 0.30632 & 0.0187 \\
\hline
\end{tabular}

Panel B: ANOVA

$\begin{array}{ccccc}\text { Sum of Squares } & d f & \begin{array}{c}\text { Mean } \\ \text { square }\end{array} & F & \text { Sig. } \\ 1.588 & 3 & 0.529 & 5.958 & 0.001 \\ 23.278 & 262 & 0.089 & & \\ 24.866 & 265 & & & \end{array}$

Panel B of Table 4 presents the results of testing hypothesis 2. Hypothesis 2 states that "There is $a$ significant difference on the performance among the students with different personality. ANOVA was used to determine whether different students' personality type influences their performance. Table 4 shows that there is a difference in the performance of students with different personality types. The results show a significant difference at $p=0.001$, thus supporting Hypothesis 2. 
This study then proceeds to examine further on the effect of the students' different personality type on their performance. The Post Hoc test was used to examine the personality type on performance. Table 5 presents the results. The results show that there is a significant difference between the Extrovert Sensing and Extrovert Intuition. The results a mean difference of -1.16803 indicating that students with Extrovert Intuition has a higher CGPA score as compared to students with Extrovert Sensing. The results show a significant difference of $p=0.000$. However, there is no significant difference between students with Extrovert Sensing and the students possessing Introvert Sensing $(p=0.765)$ and Introvert Intuition $(p=0.918)$. When comparing students possessing Extrovert Intuition with students possessing other personality types, the results also show significant difference with students with Introvert Sensing $(p=0.008)$ and students possessing Introvert Intuition $(p=0.002)$. For students possessing Introvert Sensing, the results show no significant different also with Introvert Intuition $(p=0.853)$.

Table 5: Post Hoc Test

\begin{tabular}{|c|c|c|c|c|c|c|}
\hline \multirow[t]{2}{*}{ Personality } & \multirow[t]{2}{*}{ Other Personality } & \multirow[t]{2}{*}{$\begin{array}{c}\text { Mean } \\
\text { Difference }\end{array}$} & \multirow[t]{2}{*}{$\begin{array}{c}\text { Standard } \\
\text { Error }\end{array}$} & \multirow[t]{2}{*}{ Sig. } & \multicolumn{2}{|c|}{$\begin{array}{c}\text { 95\% Confidence } \\
\text { level }\end{array}$} \\
\hline & & & & & $\begin{array}{l}\text { Lower } \\
\text { Bound }\end{array}$ & $\begin{array}{l}\text { Upper } \\
\text { Bound }\end{array}$ \\
\hline \multirow{3}{*}{$\begin{array}{l}\text { Extrovert } \\
\text { Sensing }\end{array}$} & Extrovert Intuition & -.16803 & 0.04524. & 0.000 & -.2571 & -0.0789 \\
\hline & Introvert Sensing & -.01701 & 0.05690 & 0.765 & -.1290 & 0.0950 \\
\hline & Introvert Intuition & -.00545 & 0.05303 & 0.918 & -.1099 & 0.0990 \\
\hline \multirow{3}{*}{$\begin{array}{l}\text { Extrovert } \\
\text { Intuition }\end{array}$} & Extrovert Sensing & .16803 & .04524 & 0.000 & .0789 & .2571 \\
\hline & Introvert Sensing & $.15102^{*}$ & .05607 & 0.008 & .0406 & .2614 \\
\hline & Introvert Intuition & .16257 & .05214 & 0.002 & .0599 & .2652 \\
\hline \multirow[t]{3}{*}{ Introvert Sensing } & Extrovert Sensing & .01701 & .05690 & 0.765 & -.0950 & .1290 \\
\hline & Extrovert Intuition & $-.15102^{*}$ & .05607 & 0.008 & -.2614 & -.0406 \\
\hline & Introvert Intuition & 01156 & .06252 & 0.853 & -.1116 & .1347 \\
\hline \multirow{3}{*}{$\begin{array}{l}\text { Introvert } \\
\text { Intuition }\end{array}$} & Extrovert Sensing & .00545 & .05303 & 0.918 & -.0990 & .1099 \\
\hline & Extrovert Intuition & -.16257 & .05214 & 0.002 & -.2652 & -.0599 \\
\hline & Introvert Sensing & -.01156 & 06252 & 0.853 & -.1347 & .1116 \\
\hline
\end{tabular}

\section{Summary and Conclusion}

This study attempts to determine the personality type of the accounting students in a public university in Malaysia. Specifically, this study examines the effect of the final year students' personality type on their preferred learning method and performance. This study follows Jung and 
Myer Briggs' study four personality types. However, this study only focuses on two types namely, Extrovert versus Introvert and Sensing versus Intuitive. Using questionnaire survey on 266 students, the results show that that personality type does have a role in influencing their preferred learning method. The results also show that students' personality type does influence their performance.

This study is not without limitations. One of the limitations is the sample study. This study relied on the final year accounting students in a public university in Malaysia. The findings in this study may be different if other accounting students are included in the study as well as other universities. Another limitation is the reliance on only one personality type, Extrovert versus Introvert and Sensing versus Intuition as proposed by Jung and Myers-Briggs. There are two other personality types that have not been included in this study. In sum, the findings in this study provide further understanding to the academics, faculties and university on the type of personality of the accounting students.

\section{References}

Ainley, J., Graetz, B., Long, M., \& Batten, M. (1995). Socioeconomic status and school education, Canberra, AGPS.

Anderson, G., Benjamin, D., \& Fuss, M. (1994). The determinants of success in university introductory economics course. Journal of Economic Education, 25, 99-120.

Borg, M., \& Shapiro, S. (1996). Personality type and student performance in principles of economics. Journal of Economic Education, 27, 3-25.

Bealing, W. J., Baker, R. L., Russo, C. J. (2006). Personality: What it takes to be an Accountant. Accounting Educator's Journal, 16, 119-128.

Bealing, W. J., Russo, C. J., Staley, A. B., Baker, R. L. (2007) A Short Form of The Keirsey Temperament Sorter to Predict Success in an Introductory Accounting Course. NEDSI 2007 Annual Conference Published Proceedings, San Juan, Puerto Rico, March 2007.

Bealing, W. J., Staley, A. B., Baker, R. L. (2008). Personality and Accounting: Does A Financial Aptitude Exist? NEDSI 2008 Annual Conference Published Proceedings. March 28-30.

Bisping, T. O., \& Eells, J. D. (2006). Personality type as a Determinant of Student Performance in Introductory Economics vs. Microeconomics. Journal of Economics and Economic Education Research, 7, 1, 3-28.

Borg, M. O., \& Stranahan, H. A. (2002). Personality Type and Student Performance in Upper-Level Economics Courses: The Importance of Race and Gender. Journal of Economic Education. 33(1), 3-14.

Campbell, W. M., \& Glezen, G. W. (1989). A investigation of the effect of the accounting information systems course and other variables on student performance in the first auditing course. Paper presented at the AAA Meeting, Honolulu, Hawaii.

Cheers, B. (1990). Rural disadvantage in Australia. Australian Social Work, 43(1), 5-13.

Chansarkar, B. A., Michaeloudis, A. (2001). Student profiles and factors affecting performance. International Journal Mathematics Education Science Technology, 32(1), 97-104.

Chen, R., Maksy, M. M., \& Zheng, L. (2006). Factors associated with students? Performance in advanced accounting and auditing: An empirical study in a public university. Working paper, AAA Midwest Region Meeting, Chicago. 
Christensen, T. E., Fogarthy, T. J., \& Wallace, W. A. (2002). The association between the directional accuracy of self-efficacy and accounting course. Issues in Accounting Education, 17(1), 1-26.

Deboer, G. (1984). A studying of gender effects in the science and mathematics course-taking behaviour of a group of students who graduated from college in the late 1970's. Journal of Research in Science Teaching, 21, 95-103.

Devadoss, S., \& Foltz, J. (1996). Evaluation of factors influencing student class attendance and performance. American Journal of Agricultural Economics, 78(3), 499-508.

Durden, G. C., \& Ellis, L. V. (1995). The effects of attendance on student learning in principles of economics. American Economic Review, 85(5), 343-346.

Ewer, S., Greer, O., Bridges, W., \& Lewis, B. (2002). Class length and student performance: An extended study. International Advances in Economic Research, 8(2), 160-169.

Fallan, L., \& Opstad, L. (2012). Attitudes towards Study Effort Response to Higher Grading Standards: Do Gender and Personality Distinctions Matter? Journal of Education and Learning, 1(2), 179191.

Felder, R. M., Felder, G. N., \& Dietz, E. J. (2002), The effects of personality type on engineering student performance and attitudes, Journal of Engineering Education, 91(1), 3-17.

Geleto, A. K. (2007). Factors affecting students' academic performance in higher education institutions. Working paper, Haramaya University.

Hijazi, S. T., \& Naqvi, S. M. M. (2006). Factors affecting students' performance. Bangladesh e-Journal of Sociology, 3(10), 1-10.

Horne, R. (2000). The performance of males and females in school and tertiary education. Australian Quarterly, 72(5/6), 21-26.

Jackstadt, S., \& Grootaert, C. (1980). Gender, gender stereotyping and socioeconomic background as determinants of economic knowledge and learning. Journal of Economic Education, Winter, 34-40.

Jung, C. J. (1923), Psychological types. London: Pantheon Books.

Kummerow, J. M., Barger, N. J., \& Kirby, L. K. (1997). WORK Types. New York: Warner Books.

Mattar, D. M., \& El Khoury, R. M. (2012), The interaction between accounting students' preference, teaching methodology and performance, International Journal of Social, Behavioural, Educational, Economic, Business and Industrial Engineering, 6(6), 1435-1441.

McConnell, C., \& Sosin, K. (1984). Some determinants of student attitudes toward large classes. Journal of Economic Education, 15(2), 181-190.

Meisgeier, C., Murphy, E., \& Meisgeier, C. (1989). A teacher's guide to type. Palo Alto, CA: Consulting Psychologists Press.

Muhammad, U. (1989). Comparative performance of students from Addis Ababa and other parts of the country. Unpublished thesis, Addis Ababa University, Addis Ababa.

Myers, I. (1976), Introduction to Type, Palo Alto: Consulting Psychologists Press.

Myers, I. (1998). Introduction to Type. (6th ed.), Menlo Park, CA. Consulting Psychologists Press, Inc.

Nordstrom, B. H. (1990). Predicting performance in freshman chemistry. ERIC Document Reproduction Service No. ED347065

Nourayi, M. N., \& Cherry, A. A. (1993), Accounting Students' Performance and Personality, The Journal of Education for Business, Nov/Dec, 111-115 
INTERNATIONAL JOURNAL OF ACADEMIC RESEARCH IN PSYCHOLOGY

Vol. 3, No. 1, 2016, E-ISSN: 2312-1882 @ 2016 KWP

Park, K. H., \& Kerr, P. M. (1990). Determinants of academic performance: A multinomial logit approach. Journal of Economic Education, 21, 101-111.

Pervin, L. A. (1990). Handbook of personality: Theory and research. New York: The Guilford Press.

Rogers, C. R. (1993). The interpersonal relationship in the facilitation of learning. In R. Edwards et al. (Eds.), Culture and the processes of adult learning (pp. 228-242). London: Routledge.

Rorer, L. G. (1992). Personality assessment: A conceptual study. In Review of personality and social psychology (Chapter 26). Beverly Hills: Sage Publications.

Romer, D. (1993). Do students go to class? Should they? Journal of Economic Perspectives, 7, Summer, 167-174

Russo, C. J., \& Kaynama, S. (2012), The impact of personality type and gender on students' performance in a business capstone course, Academy of Educational Leadership Journal, 16(1).

Sabot, R., \& Wakeman-Linn, J. (1991). Grade inflation and course choice. Journal of Economic Perspectives, 5(1), 159-170

Sansgiry, S. S., Bhosle, M., \& Sail, K. (2006). Factors that affect academic performance among pharmacy students. Journal of Pharmacy Education. 70(5), 104.

Schmidt, R. M. (1983). Who maximises what? A study in student time allocation. American Economic Review, 73, 23-28.

Schloemer, P. G., \& Schloemer, M. S. (1997). The personality types and preferences of CPA firm professionals: An analysis of changesin the profession. Accounting Horizons, 11(4), 24-39.

Shaver, P. (1984). Emotions, relationships, and health: The Review of Personality and Social Psychology Series \#5. Beverly Hills: Sage Publications.

Storr, A. (1983). The Essential Jung. Princeton, NJ: Princeton University Press.

Swain, R. M., \& Olsen, J. K. (2012), “From Student to Accounting Professional: A Longitudinal Study of the Filtering Process", Issues in Accounting Education, 27(1), 17-52.

Tho, L. M. (2007). Self-efficacy and student performance in an accounting course. Masalah Pendidikan, 30(2), 33-48

Swope, K. J., \& Schmitt, P. M. (2006). The Performance of Economics Graduates Over the Entire Curriculum: The Determinants of Success. The Journal of Economics Education, Fall, 37(4), 387-395.

Tsige, G. A. (2001). Effect of accommodation in academic achievement: The case of Addis Ababa Commercial College students who came from regions, Ethiopian Journal of Education, 21(2), 83-125.

Wiggins. (1991). In Wm. M. Grove \& Dante Cicchetti (Eds.), Thinking clearly about psychology: Personality and psychopathology. Vol. 2. Minneapolis: University of Minnesota Press.

Yamamura, J. H., Martin, R. M., Campbell, W. M., Campbell, S. N., Frakes, A. (2000). Performance in auditing: The effect of the accounting information systems course. Journal of Interdisciplinary Studies, Fall, 43-57. 